\title{
Introduction: The change in educational identity
} Introducción: El cambio en la identidad educativa

\author{
Carles Monereo \\ Universitat Autónoma de Barcelona
}

\begin{abstract}
In this special issue, we argue for an Educational Psychology inspired by Hubert Hermans' Dialogical Self Theory, which refutes restrictive and deterministic cognitive psychology interpretations, complements the socio-constructivist approach of classical "black box" and, explains how intra-psychological dynamics, the mental society, is created and interacts with external society. The notion of I-position and its great versatility appears as central, as well as dialogue, both in its public and private performance, as a self-dialogue. Dialogue is the basis of teaching, learning, thinking, and decision making. It is also the foundation on which the professional identity is built. Teaching, tutoring, advising, innovating, undertaking, investigating are, in short, different ways of dialoguing with ourselves and with the world, giving meaning to what we do.
\end{abstract}

Keywords: Educational Psychology; Identity Construction; Educational Personnel; SelfDialogue

\section{Resumen}

En esta sección temática abogamos por una Psicología de la Educación inspirada en la Dialogical Self Theory de Hubert Hermans, que refuta las interpretaciones restrictivas y deterministas de la psicología cognitiva, complementa el enfoque socio-constructivista de la "caja negra" clásica y explica cómo la dinámica intrapsicológica, la sociedad mental, se crea e interactúa con la sociedad externa. La noción de I-position y su gran versatilidad aparece como central, así como el diálogo, tanto en su desempeño público como privado, es decir como diálogo interno. El diálogo es el fundamento de la enseñanza, el aprendizaje, el pensamiento y la toma de decisiones. También es la base sobre la cual se construye la identidad profesional. Enseñar, tutorizar, aconsejar, innovar, emprender, investigar son, en resumen, diferentes formas de dialogar con nosotros mismos y con el mundo, dando sentido a lo que hacemos..

Palabras clave: Psicología de la Educación; Construcción de la identidad; Personal Educativo; Auto-diálogo 
Al fin y al cabo somos lo que hacemos para cambiar lo que somos. La identidad no es una pieza de museo, quietecita en su vitrina, sino la siempre asombrosa síntesis de las contradicciones nuestras de cada día.

(At the end of the day we are what we do to change what we are. Identity is not a piece of museum, still in its showcase, but the always surprising synthesis of our everyday contradictions)

Eduardo H. Galeano (1989, p. 111). El libro de los abrazos.

Educational Psychology is a discipline that has its object of study, different from general Psychology and Pedagogy: the intra-psychological processes, conscious and unconscious, promoted by inter-psychological teaching-learning processes. The degree to which these two types of processes have a relationship of independence, dependence or interdependence is what makes it possible to distinguish between different epistemological views, closer to purely cognitive approaches, according to which the relations would be of independence-Hard version-or interdependence-soft version-; or closer to socio-cultural and discursive approaches, which would underline the relationship of dependence between both.

In this last option is located the Special Issue that you have in your hands. Paraphrasing Hubert Hermans, one of today's most insightful and influential thinkers, society is in our mind, and our Self is organised as a 'mental society' with people, and their invoked voices, which continually dialogue within us (selftalk). However, also our mind is and influences society, through our public speeches and interactions.

Faced with the symbolic mind of the 'second cognitive revolution', announced in 1992 by the American Behavioural Scientist, we defend the need for a 'dialogic mind' that, curiously, also had its started in 1992 with the publication of Discursive Psychology book by Derek Edwards and Jonathan Potter. As Rom Harré already warned in the same book: 'of course, there are cognitive processes, but these are immanent to the discursive practices that are right in front of our noses' (Edwards \& Potter, 1992, p. 6).

We build ourselves through dialogue. Lev S. Vigotsky (1978), in his famous law of the double function of language, already showed that dialogue first appears as a public form of communication, and becomes internal mental communication when progressively internalized. Later, internal discourse will appear in the public discourse and be discussed with others, acquiring, perhaps, new meanings that will again be discussed in our mind. Mikhail M. Bakhtin (1981) called this process 'chains of dialogues', underlining the idea that present dia- 
logue originates as a consequence of a previous one and influences subsequent ones.

For a long time, this process of internalization or appropriation of dialogues has been treated as if it were automatic and invoking the notion of reflection seems enough to explain how it works. In those cases, reflection is interpreted as a magic mechanism that accounts for the movement from 'outside' to 'inside'. Concepts like 'reflection on, about or for action', by authors such as Donald Schön (1983), among others, made a fortune in the educational field and still remain a clear reference in psycho-educational research and intervention. Reflecting has been defined as a high order mental process, deliberate and conscious, which implies deliberating on a particular issue (e.g. from one's action to a theoretical notion). However, that said, multiple doubts arise: how does that reflection occur? Is it a regular and homogeneous process? Does it always have the same scope and depth? What does it depend on? Is it always with oneself and with the same version of oneself? What consequences does it have for learning, making decisions or interacting with others?

$\mathrm{H}$. Hermans, with the formulation of the Dialogical Self Theory (Hermans \& Gieser, 2011) has made that device more transparent, trying to explain the dialogic and dialectical dynamics that occur in our mental society and thus, shifting into different layers of grey the so-called black box. For Hermans-and for the contributing authors of this Special Issue-thinking is a matter of selfdialogue with the different I-positions that form our Identity or Self. This mental dialogue among positions and their voices is continuous, never stops, and causes our identity to be versioned in each new context, giving centrality to some I-positions instead of others. We could represent that internal dynamics as a continuous movement of approximation and distance among positions, a centrifugal and centripetal movement in which coalitions or counter-positions occur as well as third positions, or masked or hidden positions, while others promote changes, or become encysted when facing conflicts.

In this society of positions and voices that populate our mind, some positions correspond to versions of ourselves; for example, I-as-father, I-as-friend or I-as a professional; but others are invoked and belong to external voices that we internalize: the voice of my mother, of my friend, of my boss, of an author. Society, at least the closer one, is thus also represented in our mind and the boundaries between the external and the internal, the public and the private, the individual and the social, blur. The disciplinary boundaries, we usually establish to study human behaviour, at least in Psychology, are also diluted. The study of the dynamics of mind proposed by the Dialogical Self Theory is useful both to explain pathological processes, typical of Clinical Psychology, as well as 
others of an instructional nature, related to the Educational Psychology. From our point of view, validity and credibility to the Dialogical Self Theory relate to its broad scope. It constitutes a general theory explaining the global construction of the Self as an integral entity in which what matters are interactions among contexts, in which a subject acts and develops, and the different ways in which this subject positions itself in each of these contexts, means and gives meaning to its being.

Without losing sight of that integrative and holistic vision, in this Special Issue, we focus on identity dialogic construction in different contexts ranging from apprentices and future professionals to researchers, entrepreneurs or teachers.

From our psycho-educational perspective, what we finally learn is determined by the dialectic dynamics we have discussed. Therefore, learning is dialogic. Formal education situations are characterized by an initial public negotiation of meanings, usually between the teacher and classmates, triggering, simultaneously or later, an internal negotiation in which meanings are personalized and made significant. From that moment, personal meanings can be dismissed or associated with some I-position or, perhaps, trigger a more intense dialogue among positions, and eventually leading to a substantial change, contributing to re-elaborate or even to create a new one I-position. This type of learning may, as claimed by some of the contributions included in this Special Issue, have an impact on identity, and, thus on personal development and change.

This Special Issue, which an attentive reader will have already guessed cannot be a monologue, includes seven contributions. The first article, authored by Carles Monereo and Antoni Badía, attempts to explain, in greater detail, the mind dialogic dynamics and how that dynamics can transform identity, both at the individual and group level, when there is an external conflict sufficiently powerful, such as a proposal for educational innovation that affects the teaching teams of a centre.

In the second article, Mireya Giralt-Romeu, Eva Liesa, Paula Mayoral, and Lorena Becerril, identify and analyse the key learning challenges that occur during the initial teacher education and how these experiences contribute to those future teacher's identity development.

The third article is dedicated to exploring the positions of a group of teachers, experienced in pre-school and primary education. Antoni Badía, Eva Liesa, Lorena Becerril, and Paula Mayoral look at relationships between positions and factors such as the level of commitment, the relationship with colleagues and with families. 
The fourth work by Núria Suñé and Carles Monereo, refers to the support networks relevance in the success of doctoral students, contributing decisively to build a solid identity as researchers. Results showed the positive impact of 'Distributed and Active' networks, which contrasts with the negative consequences of networks considered 'Reduced and Passive'.

The fifth article by Crista Weise, Núria Suñé and Macarena Lamas also focuses on early career researcher identity, but in this case, identifying which training devices contribute most effectively to developing a research identity in a group of Master students who have chosen the speciality of research in education.

The sixth article consists of a four cases study of young entrepreneurs, representing four different identity profiles, in which Alina Valencia, analyses the critical incidents that have promoted the most important changes in participants' positions. Based on results, training for new entrepreneurs regarding how to address similar prototypical incidents is proposed.

The seventh and final article, by Kara Vloet, Ellen Klatter, Sandra Janssen and Giel Kessels, explores how a group of technology teachers face certain 'bumpy moments' and how they interpret these situations in relation to the construction of their professional identity.

According to the initial quotation with which we introduced this presentation, we are the result of the experiences, conflicts, and incidents that have destabilized us and activated our mental dialogue. Educational Psychology must study and intervene in these dialogues to introduce voices that promote personal and professional identities better prepared for such a complex society as the one we are facing.

\section{REFERENCES}

Bakhtin, Mijail (1981). The dialogic imagination: Four essays. Austin: University of Texas Press.

Edwards, Derek \& Potter, Jonathan (1992). Discoursive Psychology. London: SAGE Publication.

Galeano, Eduardo (1989). El libro de los abrazos. Madrid: Siglo XXI.

Hermans, Hubert J.M. \& Gieser, Thorsten (2011) Handbook of Dialogical Self Theory. Cambridge: Cambridge University Press.

Schön, Donald. (1983). The reflective practitioner: How professionals think in action. New York: Basic Books.

Vygotsky, Lev Semiónovich (1978). Mind in Society. Cambridge, MA: Harvard University Press. 


\section{CARLES MONEREO}

Full professor of Educational Psychology at the Universitat Autònoma de Barcelona. $\mathrm{He}$ is currently the coordinator of the SINTE research team. Her lines of research focus on the construction of professional identity, teaching and learning strategies, and the analysis of critical incidents in education.

carles.monereo@uab.cat

https://orcid.org/0000-0001-7447-985X

\section{FORMATO DE CITACIÓN}

Monereo, Carles (2020).Introduction: The change in educational identity. Quaderns de Psicologia, 22(2), e1571. http://dx.doi.org/10.5565/rev/qpsicologia.1571 